\title{
RESIDENTS' PERCEPTIONS TOWARD SUPPORT FOR TOURISM DEVELOPMENT IN SAUDI ARABIA
}

\author{
Mohammed Alawi Al-sakkaf1, ,, Zurina Mohaidin¹, and Yulita Hanum P. Iskandar ${ }^{1}$ \\ ${ }^{1}$ Graduate School of Business, Universiti Sains Malaysia, Penang, Malaysia
}

\begin{abstract}
Tourism in Saudi Arabia is rich with historical, archaeological, and cultural heritage sites all over the country. Recently, it is noticeable that Vision 2030 of Saudi Arabia asserts the importance of investment in the tourism industry as one of the most promising industries for the long-term to decrease the dependency of oil-exporting as income's resource. Nonetheless, there are a number of opportunities and threats to develop the tourism sector. However, tourism development needs support from local communities to achieve the goal of Vision 2030. Hence, the purpose of this research is to investigate the impact of tourism namely, socio-cultural, economic, and environment on the support for tourism development from local resident's perspective. Drawing upon the lenses of social exchange theory, the theoretical framework has been developed for further investigation. To assess the developed model, data will be collected from residents who live in three tourism destinations cities namely, Riyadh, Jeddah, and Dammam using self-administered questionnaire.
\end{abstract}

ARTICLE HISTORY

Received: $20-6-2020$

Accepted: 2-9-2020

\section{KEYWORDS}

Support for Tourism

Development,

Saudi Arabia,

Perceptions,

Tourism Impacts,

Social Exchange Theory

\section{INTRODUCTION}

The tourism sector generates wide opportunities for governments and individuals such as jobs' creation and foreign currencies and constitutes large numbers of macro and micro industries (World Travel \& Tourism Council - WTTC, 2019). As such, the enhancement of inbound tourists and local economic growth was recognized as the leverage of the tourism sector (Al-Tokhais \& Thapa, 2019a). In Saudi Arabia, the tourism sector contributes to USD 65.2 billion which represents $9 \%$ of the total economy, generating 1.1 million jobs or $8.5 \%$ of total employment. The tourism sector also expects 1.5 million jobs to be available in 2029 (WTTC-KSA, 2019). Saudi Arabia seeks new resources and develops other potential sectors such as tourism in order to face the reformation of a social contract (Young, 2020). Thus, Saudi's government launched Vision 2030 which focused on the tourism industry as an economic pillar toward a post-oil era (Saudi Arabia's Vision 2030, 2016). Despite the huge efforts of the Saudi tourism industry, its contribution to gross domestic product is low compared to other developed countries (Ali, 2018; WTTC, 2019). There is an ongoing talk about whether this epic change aligns with the objectives or not (Alshuwaikhat \& Mohammed, 2017). Developing tourism in Saudi Arabia, however, is still suffering from several issues such as lack of international openness including visa restricted entry, a backlash from conservative anti-tourism groups, the issue of land expropriation (Nereim, 2020; Reuters, 2019), and lack of natural and cultural resources protection (World Economic Forum-WEF, 2019). Exploring causal relations leading to such reasons may impede the competitiveness and growth of the tourism sectors in Saudi Arabia. Moreover, a study of locals' attitudes in specific destinations could provide clues or insights that marketers and managers can use in developing and promoting their tourism destination (Rasoolimanesh, Taheri, Gannon, \& Vafaei-zadeh, 2019). Therefore, it is imperative that the tourism industry in Saudi should be developed to play a vital role in economic activity over the coming years.

It is argued that the growth or even the collapse of tourism depends on the attitudes and perceptions of the host communities (Rasoolimanesh et al., 2015; Sharpley, 2014). Previous investigations revealed that the backing of tourism development related to host communities' perceptions towards sociocultural, economic, and environmental affects the tourism industry (Hammad, Ahmad, \& Papastathopoulos, 2017, 2019). Furthermore, several empirical examinations focused on residents' perceptions in mature destinations within subsequent phases of the tourism development life cycle, where the tourism dimensions are recognized (Fan, Liu, \& Qiu, 2019). However, there are limited studies exploring residents' perceptions in developing countries within the early stages of tourism development before involving in tourism initiatives or recognizing the value of tourism (Long, Ling, \& Fan, 2020; Rasoolimanesh et al., 2019).

Furthermore, in the context of Saudi Arabia, the participation of residents around tourism destinations are absent from the process of managing, planning, and protecting tourism sites (Al-Tokhais \& Thapa, 2019a, 2019b). Moreover, the literature regarding the tourism development in Saudi Arabia context is restricted to academics and religious tourism, which needs to be improved (Johnson, 2010). For example, Escudero Gómez (2019) indicated that the relationship investigating residents' perceptions regarding tourism expansion and its reflection on residents' backing of current and future tourism programs are still indecisive. Besides, only a few studies have been done in the Middle Eastern context (Alrwajfah, Almeida-García, \& Cortés-Macías, 2019) such as Saudi Arabia which recently invested in tourism 
(Alshammari \& Kim, 2019). Therefore, there is an urgent need to explore how tourism affects residents' perceptions toward supporting tourism development in Saudi Arabia.

According to Social Exchange Theory, residents will support the tourism development if they gain benefits and they will pull out their support for tourism if they incurred costs (Nunkoo \& Gursoy, 2017; Sharpley, 2014). This can explain the exchange process established on benefit and cost whether it is economically, socioculturally, or environmentally leading to backing or opposition to tourism development. (Ap, 1992). Therefore, the main purpose of this study is to investigate the relationship between residents' perceptions of tourism impacts (economic, socio-cultural, and environmental) and support for tourism development from resident's perspectives in Saudi Arabia. Three hypotheses will be developed to assess the developed model. Data will be collected from residents who live in three tourism destinations cities namely, Riyadh, Jeddah, and Dammam using a self-administered questionnaire. The study will adopt quota and convenience sampling to select 256 respondents. Partial Least Squares Structural Equation Modelling (PLS-SEM) will be used to test the study hypotheses. The results of this study will support tourism development in Saudi Arabia.

\section{LITERATURE REVIEW}

\section{Underlying Theory: Social Exchange Theory (SET)}

The first introduction of SET was by Emerson (1976) as a general theory of sociology (Rasoolimanesh et al., 2015). The basic idea of SET is that the interaction of human beings and social behaviour is fundamentally based on the exchange of tangible or intangible activities leading to benefits or costs from the process of interaction (Adongo, Kim, \& Elliot, 2019; Ap, 1992). Since the utilization of SET to interpret residents' perception of tourism effects was posited by Ap (1992), many various studies have applied SET in order to justify the exchange of resources between host communities and tourists through the social process (e.g., Nunkoo \& Ramkissoon, 2012; Gursoy et al., 2018; Hadinejad et al., 2019; Látková \& Vogt, 2012; Gursoy et al., 2002; Rasoolimanesh et al., 2015, 2017).

In the tourism field, the local citizens will prop tourism development if they perceived its influence positively and vice versa (Látková \& Vogt, 2012; Sinclair-Maragh \& Gursoy, 2016). In other words, if residents of a certain destination perceive benefits in terms of economic, social, cultural, and environmental, they will likely back up tourism development programs, while residents who perceive tourism impacts as costs for their economic, sociocultural, environmental will probably show opposition toward tourism developments ( Stylidis et al., 2014; Gursoy et al., 2002; Nazneen et al., 2019; Sharpley, 2014; Zhu et al., 2017). For instance, Sharma and Gursoy (2015) found that residents of the Sunshine Coast, Australia, show an acceptance of tourism development because of gains generated such as job opportunities, public investments, growth of local businesses, and cultural exchange between residents and visitors. Moreover, host communities often have positive perceptions of tourism development despite negative impacts (Escudero Gómez, 2019). For example, host communities perceived positive effects of economic (e.g., job creation), sociocultural (e.g., promotion of cultural activity and seasonality), and more infrastructure projects for tourism in two historical cities in India regardless of the negative impact on the environment of the destinations (Liu \& Li, 2018).

Therefore, this study will employ SET as underpinning theory in order to interpret the exchange process of the perceived tourism effects and explore the behaviour of the host community in the backing of tourism development in Saudi Arabia.

\section{Support for Tourism Development}

Tourism development refers to a conceptualized construct that includes economic, sociocultural, and environmental dimensions that have impacts on the residents of a specific destination (Rivera, Croes, \& Lee, 2016). Previous studies emphasized that the impacts of tourism development come under three categories namely, economic impacts, sociocultural impacts, and environmental impacts (Gursoy et al., 2018; Liu \& Li, 2018; Nunkoo, Smith, \& Ramkissoon, 2013). Each impact has a positive and negative influence on the local residents' attitudes and perceptions of the destination (Gursoy et al., 2018; Kim, Uysal, \& Sirgy, 2013; Loureiro, Sarmento, \& do Rosário, 2019; Lundberg, 2017; Nunkoo, 2011; Sharpley, 2014; Stylidis et al., 2014; Teye et al., 2002). Thus, the measurement of tourism impacts is based on residents' attitudes and perceptions on economic, sociocultural, environmental effects of tourism development (Lundberg, 2017; Nunkoo \& Gursoy, 2012; Sharma \& Gursoy, 2015).

In the case of economic effects, the existing literature indicated that tourism generates economic advantages to destinations through tourism programs. Therefore, the way locals perceive tourism activities on their different economic forms defines economic impacts (Stylidis et al., 2014). The economic impacts include creating jobs, bringing foreign currency, raising the income of domestic businesses, increasing governments' revenue, attracting investments, and improving the standard of living and quality of life ( Woo et al., 2019; Escudero Gómez, 2019; Garau-Vadell et al., 2018; Yu et al., 2018; Kim et al., 2013; Nazneen et al., 2019; Sinclair-Maragh \& Gursoy, 2016; Su et al., 2019; Summers et al., 2019). Likewise, tourism may also incur costs such as the trade-off between projects related to tourism development and other investments related to the public (Fan et al., 2019), tourism revenue leakage (Sarma \& Pais, 2008). Tourism may also increase residents' living costs, real estate prices, and rents (Biagi, Ladu, Meleddu, \& Royuela, 2019; Liu \& Li, 2018; Rasoolimanesh et al., 2015).

Furthermore, tourism development also affects the sociocultural life and routine of local host communities (Hammad et al., 2017). Thus, the way citizens of destination perceive tourism activities on their different sociocultural aspects is referred to as sociocultural impacts of tourism development (Stylidis et al., 2014). Nonetheless, several examinations reported that sociocultural factor can lead to positive or negative impacts perceived by local residents of destination 
(Gursoy et al., 2018; N. Hammad et al., 2017; Kim et al., 2013; Sharma \& Gursoy, 2015; Stylidis et al., 2014; Zhu et al., 2017). For instance, the exchange of culture and experience catalyses the social capital and life's quality of local communities (Summers et al., 2019). Furthermore, the social benefit includes improving the effective hospitality and accommodation experience to visitors and promoting trust and social tolerance (Fan et al., 2019; Kim et al., 2013). Social benefits also include the availability of multiple aspects of cultural, historical, and ecological that lead to more outdoor recreation, leisure, entertainment programs, which improve the level quality of public services at the destination (Yu et al., 2018). Otherwise, residents may perceive sociocultural impacts negatively such as disrupting residents' living style, suffering from living in tourism destination over time (Sharma \& Gursoy, 2015), bringing traffic jams issues and overcrowding to public areas (Kim et al., 2013), destructing aboriginal culture (Eshliki \& Kaboudi, 2012), and increasing the crime rate, gambling, prostitution, alcoholism, and other disasters to the host community ( Teye et al., 2002; Biagi, Brandano, \& Detotto, 2012; Deery et al., 2012; García et al., 2015; Stylidis et al., 2014;).

In relation to environmental effects, the way locals perceive tourism's influence on various environmental aspects is referred to as perceived environmental impacts (Kim et al., 2013; Stylidis et al., 2014). Many studies demonstrated that tourism development has both negative and positive environmental impacts (Almeida-García et al., 2016; Aref, Redzuan, \& Gill, 2009; Kim et al., 2013; Szromek, Kruczek, \& Walas, 2019). In regards to positive impacts, tourism development may be the reason to protect and preserve the natural environment from damaging the ecosystem of the destination ( Nunkoo \& So, 2016; Almeida-García et al., 2016). Moreover, environmental awareness could be a reason why local communities and governments are supporting further tourism growths in a destination (Su et al., 2019). In terms of the negative side, residents may perceive tourism development negatively due to congestion, pollution, natural landscape damage, and garbage problems (Liu \& Li, 2018; Nunkoo \& So, 2016; Nunkoo \& Ramkissoon, 2012; Nunkoo et al., 2013). Moreover, the destructive effect of environmental pollution gradually increases over time which decreases the quality environment of the destination (Gupta \& Dutta, 2018).

\section{Hypotheses Development}

The following hypotheses were developed according to SET, extant literature, and the objectives of this study. The relationship between perceived economic, sociocultural, and environmental impacts and support for tourism development was drawn.

Previous literature emphasized that the perceptions of locals regarding economic, sociocultural, environmental impacts of tourism are antecedents for tourism evolution contingent on the estimation of how residents perceived tourism (Garau-Vadell et al., 2019; Gursoy et al., 2018; Lee \& Jan, 2019; Stylidis et al., 2014; Lin, Chen, \& Filieri, 2017; Sharpley, 2014; Liu \& Li, 2018; Rasoolimanesh et al., 2015, 2017). According to SET, if locals perceived values that are representative of economic, sociocultural, or environmental factors positively due to tourism activities, they will likely support tourism growth. Likewise, they will stop supporting any tourism programs because of how it affects them economically, socially, or environmentally (Stylidis et al., 2014; Ap, 1992; Nunkoo \& Gursoy, 2017; Sharpley, 2014). That means the actions (e.g., benefit and/or costs) generated from tourism activities determines the reaction of locals (e.g., support / oppose) on tourism growth. The latter is measured by the psychological attitude (Hadinejad et al., 2019).

Despite the plethora of studies, the results of the relationship between residents' perceptions of tourism impacts and support for tourism development are inconclusive (Escudero Gómez, 2019). For example, negative social and cultural influence on citizens of Abu Dhabi did not change their attitude towards tourism growth (Hammad et al., 2017). Meanwhile, other investigations concluded that locals may oppose tourism development because they perceived negatively the sociocultural impact of tourism (Deery \& Jago, 2010).

Nevertheless, the measurements of residents' perceptions based on prejudgment of the positive or negative tourism impacts could not reflect the attitude of residents in a proper way (Stylidis et al., 2014). Hence, gauging residents' perceptions toward tourism development based on a "non-forced approach" enables them to express and explain their own perception of tourism impacts in terms of benefits and costs. Furthermore, Gursoy et al. (2018) revealed that utilizing current measurements in order to estimate the perceived negative impacts of tourism could have a validity issue. Consequently, the hypotheses adopt a positive non-forced approach based on SET and extant literature as follows:

H1: Economic impact is positively related to residents' support for tourism development in Saudi Arabia.

H2: Sociocultural impact is positively related to residents' support for tourism development in Saudi Arabia.

H3: Environmental impact is positively related to residents' support for tourism development in Saudi Arabia.

\section{Proposed model}

Based on the literature reviewed and suggestions by several studies, this study developed a model to investigate the relationship between perceptions of tourism dimensions and support for tourism development in Saudi Arabia. We developed a conceptual model (Figure 1) that represents three independent variables of tourism impacts namely, perceived economic impacts, perceived sociocultural impacts, and perceived environmental impacts and the dependent variable represents support for tourism development. 


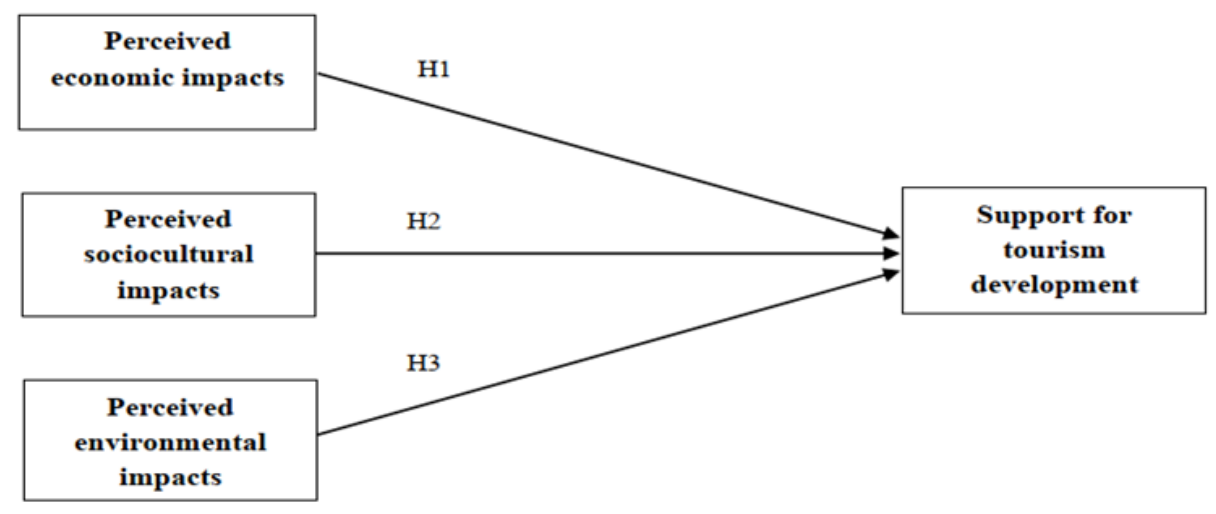

Figure 1: Conceptual model

\section{METHODOLOGY}

This study was quantitative and cross-sectional, aimed to examine residents' perceptions of tourism impacts and support for tourism development in Saudi Arabia. The target population of interest for this study was the permanent residents who have a minimum age of 18 and live in the city of Riyadh, Jeddah, and Dammam in Saudi Arabia. According to the tourism information and research centre (MAS, 2018), the three cities are the highest target destinations for tourism and leisure by domestic and international visitors. Furthermore, these cities are also representing the characteristics of geographic, demographic, social, and cultural differences in Saudi Arabia. Riyadh (the capital) is located in the middle region, Jeddah is the coastal city of Red Sea in the western region which is also known as "Gate of Makka", and Dammam is in the eastern region which is located in the Persian Gulf, geographically nearby other gulf countries of Qatar, Bahrain, and UAE (Saudi Arabia Tourism Guide - SATG, 2017).

The participants will be individuals aged 18 and above (permanent residents who lived at least one year in the host tourism cities) in Saudi Arabia. Saudi Arabia has 70\% of the total population below the age of 30 (General Authority for Statistics, 2016). This young generation has awareness and understanding of tourism, tends to spend more leisure time for tourism, and is less conservative toward new tourism experiences (Alshammari \& Kim, 2019). In determining the suitable sample size for this study, power analysis as a statistical method will be carried out using the software of G*Power 3.1. Using the statistical parameters and eleven interactions (direct, indirect, and moderating effect), a minimum sample of 178 would be required to test regression-based models (Faul, Erdfelder, Buchner, \& Lang, 2009). Due to the poor response rate, the sample size will be increased by $50 \%$.

The technique used in the sampling will either be probabilistic or non-probabilistic. For this study, since there are three areas (cities) covered, this study will employ the quota sampling technique which is a type of non-probability sampling technique in each city totalling 256 of sample size. Then, convenience sampling will be utilized to select the participants of the study. This is consistent with several previous studies (e.g., Fan, Zhang, Jenkins, \& Lin, 2017; Liang \& Hui, 2016).

A self-administrative survey method will be used for the data collection procedure. The questionnaire will be given to the participants who live in the three cities via face-to-face surveys. The participants will be conveniently chosen from tourism destinations in these cities. This is consistent with several previous studies (e.g., Liang \& Hui, 2016; Wang, Chen, $\& \mathrm{Xu}, 2017$ ). To analyse the statistical data, this study will use Structural Equation Modelling (SEM) with Partial Least Squares (PLS) software version 3.2.8 to test the research hypotheses and Statistical Package for Social Sciences (SPSS) analysis package software (version 24) to analyse the demographics data.

\section{SIGNIFICANT OF STUDY}

This study will contribute to both management theories and practical applications for the tourism industry in Saudi Arabia. Firstly, from a theoretical perspective, it extends the theoretical ground to cover three elementary tourism dimensions which are sociocultural, economic, and environmental effects. This study will provide a structural framework and measurements approach for collecting data in three tourism destination cities, as well as provide deep insights for future similar research topics in the context of Saudi Arabia. Secondly, the measurement of constructs will utilize a nonforce approach to explore residents' perceptions of tourism impacts. This will offer more freedom in answering the questions and determine the positive or negative impacts, specifically at initial phases of tourism development. Thirdly, this study provides an opportunity for testing the theory of social exchange in the emerging economy. Next, from a practical perspective, this study provides information for policymakers, managers, and marketers to improve the positive 
factors of tourism and minimize the impacts of negative factors. Such information is significant in developing sustainable tourism strategies by recognizing and handling the positive and negative characteristics that affect host communities' perceptions.

\section{CONCLUSION}

The government of Saudi Arabia is committed to accomplishing its national transformation plan since it launched the Saudi Vision 2030. Tourism was considered as one of the economic diversification pillars in order to overcome the postoil era. Tourism development does not only generated benefits but also incurred costs. Once a destination turns into a tourism destination, locals' life will be affected by these tour projects. These effects drive changes in the residents' values, behaviours, lifestyle, and even life quality. The current study is designed to determine the perceived impacts of tourism in terms of economic, sociocultural aspects, and environment on support for tourism development from the perspectives of host communities in Saudi Arabia. The expected findings will offer guidelines in fulfilling the requirements of accomplishment tourism competitiveness objectives in Saudi Vision 2030.

\section{REFERENCES}

Adongo, R., (Sam) Kim, S., \& Elliot, S. (2019). "Give and take": A social exchange perspective on festival stakeholder relations. Annals of Tourism Research, 75(December 2018), 42-57. https://doi.org/10.1016/j.annals.2018.12.005

Al-Tokhais, A., \& Thapa, B. (2019a). Management issues and challenges of UNESCO World Heritage Sites in Saudi Arabia. Journal of Heritage Tourism, 0(0), 1-8. https://doi.org/10.1080/1743873X.2019.1594836

Al-Tokhais, A., \& Thapa, B. (2019b). Stakeholder perspectives towards national parks and protected areas in Saudi Arabia. Sustainability (Switzerland), 11(8), 1-15. https://doi.org/10.3390/su11082323

Ali, A. (2018). Travel and tourism: Growth potentials and contribution to the GDP of Saudi Arabia. Problems and Perspectives in Management, 16(1), 417-427. https://doi.org/10.21511/ppm.16(1).2018.39

Almeida-García, F., Peláez-Fernández, M. Á., Balbuena-Vázquez, A., \& Cortés-Macias, R. (2016). Residents’ perceptions of tourism development in Benalmádena (Spain). Tourism Management, 54, 259-274. https://doi.org/10.1016/j.tourman.2015.11.007

Alrwajfah, M., Almeida-García, F., \& Cortés-Macías, R. (2019). Residents' Perceptions and Satisfaction toward Tourism Development: A Case Study of Petra Region, Jordan. Sustainability, 11(7), 1907. https://doi.org/10.3390/su11071907

Alshammari, F., \& Kim, Y. K. (2019). Seeking and escaping in a Saudi Arabian festival. International Journal of Event and Festival Management. https://doi.org/10.1108/IJEFM-02-2018-0015

Alshuwaikhat, H. M., \& Mohammed, I. (2017). Sustainability matters in national development visions-Evidence from Saudi Arabia's vision for 2030. Sustainability (Switzerland), 9(3), 18-20. https://doi.org/10.3390/su9030408

Ap, J. (1992). Residents' perceptions on tourism impacts. Annals of Tourism Research, 19(4), 665-690. https://doi.org/10.1016/01607383(92)90060-3

Aref, F., Redzuan, M., \& Gill, S. S. (2009). Community Perceptions toward Economic and Environmental Impacts of Tourism on Local Communities. Asian Social Science, 5(7). https://doi.org/10.5539/ass.v5n7p130

Biagi, B., Brandano, M. G., \& Detotto, C. (2012). The Effect of Tourism on Crime in Italy: A Dynamic Panel Approach. Economics: The Open-Access, Open-Assessment E-Journal, 6(2012-25), 1. https://doi.org/10.5018/economics-ejournal.ja.2012-25

Biagi, B., Ladu, M. G., Meleddu, M., \& Royuela, V. (2019). Tourism and the city: The impact on residents' quality of life. International Journal of Tourism Research, (July), 1-14. https://doi.org/10.1002/jtr.2326

Chancellor, C., Yu, C. S., \& Cole, S. T. (2011). Exploring quality of life perceptions in rural midwestern (USA) communities: an application of the core-periphery concept in a tourism development context. International Journal of Tourism Research, 13(5), 496-507. https://doi.org/10.1002/jtr.823

Chen, Z., Wang, Y., Li, X. (Robert), \& Lawton, L. (2019). It's Not Just Black or White: Effects of Ambivalence on Residents' Support for a Mega-Event. Journal of Hospitality and Tourism Research, 43(2), 283-313. https://doi.org/10.1177/1096348018804613

Deery, M., \& Jago, L. (2010). Social impacts of events and the role of anti-social behaviour. International Journal of Event and Festival Management, 1(1), 8-28. https://doi.org/10.1108/17852951011029289

Deery, M., Jago, L., \& Fredline, L. (2012). Rethinking social impacts of tourism research: A new research agenda. Tourism Management, 33(1), 64-73. https://doi.org/10.1016/j.tourman.2011.01.026

Emerson, R. M. (1976). Social Exchange Theory. Annual Review of Sociology, 2(1), 335-362. https://doi.org/10.1146/annurev.so.02.080176.002003

Escudero Gómez, L. A. (2019). Residents' Opinions and Perceptions of Tourism Development in the Historic City of Toledo, Spain. Sustainability, 11(14), 3854. https://doi.org/10.3390/su11143854

Eshliki, S. A., \& Kaboudi, M. (2012). Community Perception of Tourism Impacts and Their Participation in Tourism Planning: A Case Study of Ramsar, Iran. Procedia - Social and Behavioral Sciences, 36(June 2011), $333-341$. https://doi.org/10.1016/j.sbspro.2012.03.037

Fan, D. X. F., Liu, A., \& Qiu, R. T. R. (2019). Revisiting the relationship between host attitudes and tourism development: A utility maximization approach. Tourism Economics, 25(2), 171-188. https://doi.org/10.1177/1354816618794088

Fan, D. X. F., Zhang, H. Q., Jenkins, C. L., \& Lin, P. M. C. (2017). Does Tourist-Host Social Contact Reduce Perceived Cultural Distance? Journal of Travel Research, 56(8), 998-1010. https://doi.org/10.1177/0047287517696979 
Faul, F., Erdfelder, E., Buchner, A., \& Lang, A.-G. (2009). Statistical power analyses using G*Power 3.1: Tests for correlation and regression analyses. Behavior Research Methods, 41(4), 1149-1160. https://doi.org/10.3758/BRM.41.4.1149

Garau-Vadell, J. B., Gutierrez-Taño, D., \& Diaz-Armas, R. (2018). Economic crisis and residents' perception of the impacts of tourism in mass tourism destinations. Journal of Destination Marketing \& Management, 7, 68-75. https://doi.org/10.1016/j.jdmm.2016.08.008

Garau-Vadell, J. B., Gutiérrez-Taño, D., \& Díaz-Armas, R. (2019). Residents' Support for P2P Accommodation in Mass Tourism Destinations. Journal of Travel Research, 58(4), 549-565. https://doi.org/10.1177/0047287518767067

García, F. A., Vázquez, A. B., \& Macías, R. C. (2015). Resident's attitudes towards the impacts of tourism ఓz. TMP, 13, 33-40. https://doi.org/10.1016/j.tmp.2014.11.002

General Authority for Statistics. (2016). Demography Survey 2016, 207. Retrieved from http://www.stats.gov.sa/sites/default/files/ardemographic-research-2016_0.pdf

Goffi, G., Cucculelli, M., \& Masiero, L. (2019). Fostering tourism destination competitiveness in developing countries: The role of sustainability. Journal of Cleaner Production, 209, 101-115. https://doi.org/10.1016/j.jclepro.2018.10.208

Gupta, M. R., \& Dutta, P. B. (2018). Tourism development, environmental pollution and economic growth: A theoretical analysis. Journal of International Trade and Economic Development, 27(2), 125-144. https://doi.org/10.1080/09638199.2017.1346139

Gursoy, D., Jurowski, C., \& Uysal, M. (2002). Resident attitudes: A structural modeling approach. Annals of Tourism Research, 29(1), 79-105. https://doi.org/10.1016/S0160-7383(01)00028-7

Gursoy, D., Ouyang, Z., Nunkoo, R., \& Wei, W. (2018). Residents ' impact perceptions of and attitudes towards tourism development : a meta-analysis. Journal of Hospitality Marketing \& Management, 00(00), 1-28. https://doi.org/10.1080/19368623.2018.1516589

Hadinejad, A., D. Moyle, B., Scott, N., Kralj, A., \& Nunkoo, R. (2019). Residents' attitudes to tourism: a review. Tourism Review, 74(2), 150-165. https://doi.org/10.1108/TR-01-2018-0003

Hammad, N., Ahmad, S. Z., \& Papastathopoulos, A. (2017). Residents' perceptions of the impact of tourism in Abu Dhabi, United Arab Emirates. International Journal of Culture, Tourism, and Hospitality Research, 11(4), 551-572. https://doi.org/10.1108/IJCTHR-04-2017-0048

Hammad, N. M., Ahmad, S. Z., \& Papastathopoulos, A. (2019). The moderating role of nationality in residents' perceptions of the impacts of tourism development in the United Arab Emirates. International Journal of Tourism Research, 21(1), 61-75. https://doi.org/10.1002/jtr.2241

Hsu, C., Chen, M., \& Yang, S.-C. (2019). Residents' Attitudes toward Support for Island Sustainable Tourism. Sustainability, 11(18), 5051. https://doi.org/10.3390/su11185051

Joanne Johnson, D. (2010). Chapter 7 Tourism in Saudi Arabia. In Bridging Tourism Theory and Practice (Vol. 2, pp. 91-106). https://doi.org/10.1108/S2042-1443(2010)0000002010

Kim, K., Uysal, M., \& Sirgy, M. J. (2013). How does tourism in a community impact the quality of life of community residents? Tourism Management, 36, 527-540. https://doi.org/10.1016/j.tourman.2012.09.005

Látková, P., \& Vogt, C. A. (2012). Residents' attitudes toward existing and future tourism development in rural communities. Journal of Travel Research, 51(1), 50-67. https://doi.org/10.1177/0047287510394193

Lee, T. H., \& Jan, F. H. (2019). Can community-based tourism contribute to sustainable development? Evidence from residents' perceptions of the sustainability. Tourism Management, 70(September 2017), 368-380. https://doi.org/10.1016/j.tourman.2018.09.003

Liang, Z. X., \& Hui, T. K. (2016). Residents' quality of life and attitudes toward tourism development in China. Tourism Management, 57, 56-67. https://doi.org/10.1016/j.tourman.2016.05.001

Lin, Z., Chen, Y., \& Filieri, R. (2017). Resident-tourist value co-creation: The role of residents' perceived tourism impacts and life satisfaction. Tourism Management, 61, 436-442. https://doi.org/10.1016/j.tourman.2017.02.013

Liu, X. R., \& Li, J. J. (2018). Host perceptions of tourism impact and stage of destination development in a developing country. Sustainability (Switzerland), 10(7), 1-15. https://doi.org/10.3390/su10072300

Long, X., Ling, M., \& Fan, D. X. F. (2020). Land expropriation in tourism development: Residents' attitudinal change and its influencing mechanism. Tourism Management, 76(August 2019), 103957. https://doi.org/10.1016/j.tourman.2019.103957

Loureiro, S. M. C., Sarmento, E. M., \& do Rosário, J. F. (2019). Overview of underpinnings of tourism impacts. In The Routledge Handbook of Tourism Impacts (pp. 49-61). Abingdon, Oxon; New York, NY: Routledge, 2019.: Routledge. https://doi.org/10.4324/9781351025102-4

Lundberg, E. (2017). The importance of tourism impacts for different local resident groups: A case study of a Swedish seaside destination. Journal of Destination Marketing and Management, 6(1), 46-55. https://doi.org/10.1016/j.jdmm.2016.02.002

MAS. (2018). KEY INDICATORS OF TOURISM DEMAND IN KINGDOM OF SAUDI ARABIA 2016 - 2018. Retrieved September 18, 2019, from http://www.mas.gov.sa/infographics

Muresan, I. C., Harun, R., Arion, F. H., Oroian, C. F., Dumitras, D. E., Mihai, V. C., ... Chiciudean, G. O. (2019). Residents' perception of destination quality: Key factors for sustainable rural development. Sustainability (Switzerland), 11(9), 1-21. https://doi.org/10.3390/su11092594

Nazneen, S., Xu, H., \& Din, N. U. (2019). Cross-border infrastructural development and residents' perceived tourism impacts: A case of China-Pakistan Economic Corridor. International Journal of Tourism Research, 21(3), 334-343. https://doi.org/10.1002/jtr.2264 
Nereim, V. (2020). Hope Turns to Doubt, Then Gunfire, as Saudi Megacity Emerges - Bloomberg. Retrieved August 8, 2020, from https://www.bloomberg.com/news/articles/2020-04-24/hope-turns-to-doubt-then-gunfire-as-new-saudi-megacity-emerges

Nunkoo, R. (2011). DEVELOPING A COMMUNITY SUPPORT MODEL FOR TOURISM. Annals of Tourism Research, 38(3), 964-988. https://doi.org/10.1016/j.annals.2011.01.017

Nunkoo, R., \& Gursoy, D. (2012). Residents' support for tourism. Annals of Tourism Research, 39(1), $243-268$. https://doi.org/10.1016/j.annals.2011.05.006

Nunkoo, R., \& Gursoy, D. (2017). Political trust and residents' support for alternative and mass tourism: an improved structural model. Tourism Geographies, 19(3), 318-339. https://doi.org/10.1080/14616688.2016.1196239

Nunkoo, R., \& Ramkissoon, H. (2012). Power, trust, social exchange and community support. Annals of Tourism Research, 39(2), 997-1023. https://doi.org/10.1016/j.annals.2011.11.017

Nunkoo, R., Smith, S. L. J., \& Ramkissoon, H. (2013). Residents' attitudes to tourism: A longitudinal study of 140 articles from 1984 to 2010. Journal of Sustainable Tourism, 21(1), 5-25. https://doi.org/10.1080/09669582.2012.673621

Nunkoo, R., \& So, K. K. F. (2016). Residents' Support for Tourism: Testing Alternative Structural Models. Journal of Travel Research, 55(7), 847-861. https://doi.org/10.1177/0047287515592972

Rasoolimanesh, S. M., Jaafar, M., Kock, N., \& Ramayah, T. (2015). A revised framework of social exchange theory to investigate the factors influencing residents' perceptions. Tourism Management Perspectives, 16, 335-345. https://doi.org/10.1016/j.tmp.2015.10.001

Rasoolimanesh, S. M., Ringle, C. M., Jaafar, M., \& Ramayah, T. (2017). Urban vs . rural destinations : Residents ' perceptions , community participation and support for tourism development. Tourism Management, 60, 147-158. https://doi.org/10.1016/j.tourman.2016.11.019

Rasoolimanesh, S. M., Taheri, B., Gannon, M., \& Vafaei-zadeh, A. (2019). Does living in the vicinity of heritage tourism sites influence residents, perceptions and attitudes? Journal of Sustainable Tourism, 27(9), $1295-1317$. https://doi.org/10.1080/09669582.2019.1618863

Reuters. (2019). Three performers stabbed at Saudi entertainment event -state TV - Reuters. Retrieved August 8, 2020, from https://www.reuters.com/article/saudi-stabbings/three-performers-stabbed-at-saudi-entertainment-event-state-tvidUSL8N27R6P1

Rivera, M., Croes, R., \& Lee, S. H. (2016). Tourism development and happiness: A residents' perspective. Journal of Destination Marketing and Management, 5(1), 5-15. https://doi.org/10.1016/j.jdmm.2015.04.002

Sarma, M., \& Pais, J. (2008). Financial Inclusion and Development: A Cross Country Analysis. In Annual Conference of the Human Development and Capability Association, New Delhi, 168(10-13), 1-30. https://doi.org/10.1002/jid

SATG. (2017). Provinces - Saudi Arabia Tourism Guide. Retrieved August 11, 2020, from http://www.saudiarabiatourismguide.com/provinces/

Saudi Arabia's Vision 2030. (2016). Foreword | Saudi Vision 2030. Retrieved March 26, 2019, from https://vision2030.gov.sa/en/foreword

Sharma, B., \& Gursoy, D. (2015). An Examination of Changes in Residents' Perceptions of Tourism Impacts Over Time: The Impact of Residents' Socio-demographic Characteristics. Asia Pacific Journal of Tourism Research, 20(12), 1332-1352. https://doi.org/10.1080/10941665.2014.982665

Sharpley, R. (2014). Host perceptions of tourism: A review of the research. Tourism Management, 42, 37-49. https://doi.org/10.1016/j.tourman.2013.10.007

Sinclair-Maragh, G., \& Gursoy, D. (2016). A Conceptual Model of Residents' Support for Tourism Development in Developing Countries. Tourism Planning \& Development, 13(1), 1-22. https://doi.org/10.1080/21568316.2015.1047531

Stylidis, D., Biran, A., Sit, J., \& Szivas, E. M. (2014). Residents' support for tourism development: The role of residents' place image and perceived tourism impacts. Tourism Management, 45, 260-274. https://doi.org/10.1016/j.tourman.2014.05.006

Su, M. M., Wall, G., Wang, Y., \& Jin, M. (2019). Livelihood sustainability in a rural tourism destination - Hetu Town, Anhui Province, China. Tourism Management, 71(October 2018), 272-281. https://doi.org/10.1016/j.tourman.2018.10.019

Summers, J., Cavaye, J., \& Woolcock, G. (2019). Enablers and Barriers of Tourism as a Driver of Economic and Social-cultural Growth in Remote Queensland. Economic Papers, 38(2), 77-94. https://doi.org/10.1111/1759-3441.12246

Szromek, A. R., Kruczek, Z., \& Walas, B. (2019). The Attitude of Tourist Destination Residents towards the Effects of OvertourismKraków Case Study. Sustainability, 12(1), 228. https://doi.org/10.3390/su12010228

Teye, V., Sirakaya, E., \& F. Sönmez, S. (2002). Residents' attitudes toward tourism development. Annals of Tourism Research, 29(3), 668-688. https://doi.org/10.1016/S0160-7383(01)00074-3

Wang, S., Chen, S., \& Xu, H. (2017). Resident attitudes towards dark tourism , a perspective of place-based identity motives. Current Issues in Tourism, 0(0), 1-16. https://doi.org/10.1080/13683500.2017.1390553

WEF-TTCI. (2019). The Travel \& Tourism Competitiveness Report 2019: Travel and Tourism at a Tipping Point. World Economic Forum. Geneva: the World Economic Forum's Platform for Shaping the Future of Mobility. Retrieved from https://www.weforum.org/reports/the-travel-tourism-competitiveness-report-2019

Woo, E., Uysal, M., \& Sirgy, M. J. (2019). What Is the Nature of the Relationship Between Tourism Development and the Quality of Life of Host Communities? In A. M. Campón-Cerro, J. M. Hernández-Mogollón, \& J. A. Folgado-Fernández (Eds.), Best Practices in Hospitality and Tourism Marketing and Management (pp. 43-62). Cham: Springer.

WTTC-KSA. (2019). SAUDI ARABIA-2019 ANNUAL RESEARCH: KEY HIGHLIGHTS. 
WTTC. (2019). TRAVEL \& TOURISM ECONOMIC IMPACT 2019 WORLD. London.

Young, K. E. (2020). Sovereign risk: Gulf sovereign wealth funds as engines of growth and political resource. British Journal of Middle Eastern Studies, 00(00), 1-21. https://doi.org/10.1080/13530194.2020.1714866

Yu, C. P., Cole, S. T., \& Chancellor, C. (2018). Resident support for tourism development in rural midwestern (USA) communities: Perceived tourism impacts and community quality of life perspective. Sustainability (Switzerland), 10(3). https://doi.org/10.3390/su10030802

Zhu, H., Liu, J., Wei, Z., Li, W., \& Wang, L. (2017). Residents' attitudes towards sustainable tourism development in a historicalcultural village: Influence of perceived impacts, sense of place and tourism development potential. Sustainability (Switzerland), 9(1). https://doi.org/10.3390/su9010061

Zhuang, X., Lin, L., \& Li, J. J. (2019). Puri vs. Varanasi destinations: local residents' perceptions, overall community satisfaction and support for tourism development. Journal of the Asia Pacific Economy, 24(1), $127-142$. https://doi.org/10.1080/13547860.2019.1572689

\section{AUTHORS' BIOGRAPHY}

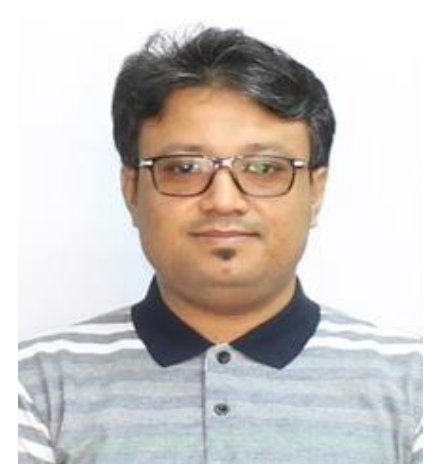

Mohammed Alawi Al-sakkaf is a Doctoral Candidate at Graduate School of Business (GSB), Universiti Sains Malaysia. His current research focus on residents' perceptions, tourism development and its impacts, quality of life, and destination social responsibility.

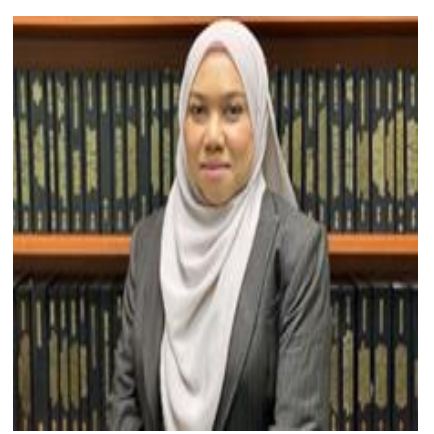

Dr. Zurina Mohaidin is a Marketing lecturer in Graduate School of Business. She currently teaches Marketing Management for postgraduates and has been supervising a number of PhD and MBA students. She graduated her PhD from Cardiff University, United Kingdom with an MBA and BSc in Marketing from University of Bridgeport, Connecticut, United States. Dr Zurina is also the Program Manager for the MBA program of Graduate School of Business. Dr. Zurina has presented numerous papers in conferences and published research articles in well-known journals. Her research has been on Marketing and Consumer Behaviour, looking at the branding and consumer choices.

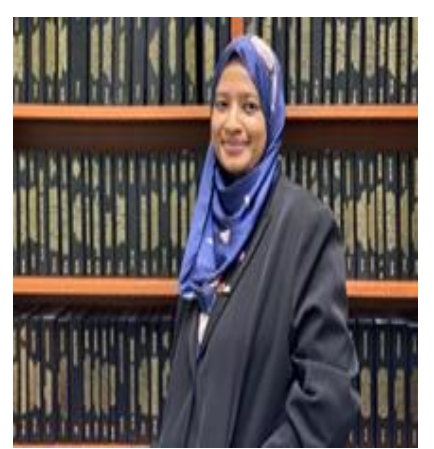

Yulita Hanum P. Iskandar who was originally trained in computing is a Senior Lecturer in Graduate School of Business, Universiti Sains Malaysia. She currently teaches 'Management Information Systems' and 'Technology Management' for postgraduates and specializes in research related to technological and innovation. 